\title{
PD-1/PD-L1 Interaction Maintains Allogeneic Immune Tolerance Induced by Administration of Ultraviolet B-Irradiated Immature Dendritic Cells
}

\author{
Lanfang Zhang ${ }^{1,2}$ and Chang-Qing Xia ${ }^{1,3}$ \\ ${ }^{1}$ Department of Hematology, Xuanwu Hospital, Capital Medical University, Beijing 100053, China \\ ${ }^{2}$ Department of Chemotherapy, Weihai Municipal Hospital, Weihai 264200, China \\ ${ }^{3}$ Department of Pathology, Immunology and Laboratory Medicine, University of Florida, Gainesville, FL 32610, USA
}

Correspondence should be addressed to Chang-Qing Xia; cqx65@yahoo.com

Received 21 March 2016; Revised 5 June 2016; Accepted 3 July 2016

Academic Editor: Moisés E. Bauer

Copyright ( 2016 L. Zhang and C.-Q. Xia. This is an open access article distributed under the Creative Commons Attribution License, which permits unrestricted use, distribution, and reproduction in any medium, provided the original work is properly cited.

\begin{abstract}
Our previous study demonstrated that transfusion of ultraviolet B-irradiated immature dendritic cells (UVB-iDCs) induced alloantigen-specific tolerance between two different strains of mice. Programmed death-1 (PD-1) and programmed death ligand-1 (PD-L1) have been suggested to play an important role in maintaining immune tolerance. In the present study, we seek to address whether PD-1/PD-L1 plays a role in the maintenance of UVB-iDC-induced tolerance. We first observe that the UVB-iDC-induced alloantigen-specific tolerance can be maintained for over 6 weeks. Supporting this, at 6 weeks after tolerance induction completion, alloantigen-specific tolerance is still able to be transferred to syngeneic naïve mice through adoptive transfer of CD4+ T cells. Furthermore, skin transplantation study shows that the survival of allogeneic grafts is prolonged in those tolerant recipients. Further studies show that PD-1/PD-L1 interaction is essential for maintaining the induced tolerance as blockade of PD-1/PD-L1 by antiPD-L1 antibodies largely breaks the tolerance at both cellular and humoral immunological levels. Importantly, we show that PD1/PD-L1 interaction in tolerant mice is also essential for controlling alloantigen-responding $\mathrm{T}$ cells, which have never experienced alloantigens. The above findings suggest that PD-1/PD-L1 plays a crucial role in maintaining immune tolerance induced by UVBiDCs, as well as in actively controlling effector T cells specific to alloantigens.
\end{abstract}

\section{Introduction}

The major obstacle of allogeneic transplantation is the allograft rejection due to mismatched major histocompatibility complex (MHC) antigens $[1,2]$. Induction of immune tolerance across MHC barrier is an ideal approach for preventing allograft rejection. It has been demonstrated that steady-state cell apoptosis during self-renewal plays an important role in maintaining immune tolerance to self-antigens $[3,4]$. In line with this, we have successfully induced immune tolerance to alloantigens between two different mouse strains through injection of ultraviolet B- (UVB-) irradiated immature dendritic cells (UVB-iDCs) and infusion of iDCs without UVB irradiation mounts potent immune response to alloantigens $[5,6]$. Using this approach, we were able to significantly prevent graft-versus-host disease in a mouse model of allogeneic hematopoietic stem cell transplantation [5]. However, how this UVB-iDC-induced tolerance is maintained remains to be determined.

The interaction of programmed death-1 (PD-1) and its ligand (PD-L1) has been proposed to be involved in the modulation of both central and peripheral tolerance [7]. Studies showed that PD-1/PD-L1 interaction was required for both induction and maintenance of $\mathrm{T}$ cell tolerance [8-10]. In an alloantigen tolerance induction model, it was shown that PD-1/PD-L1 plays an important role in maintaining longterm allogeneic tolerance induced by infusion of ethylene carbodiimide-fixed allogeneic splenocytes [11]. In our previous study, we demonstrated a significantly prolonged survival in the recipients receiving bone marrow and spleen cells from donor mice tolerant to alloantigens induced by infusion of UVB-iDCs in an allogeneic hematopoietic stem cell 
transplantation mouse model [5], suggesting that UVB-iDCinduced immune tolerance to allogeneic MHC antigens could be long lasting. In this study, we firstly addressed whether UVB-iDCs treatment-induced alloantigen tolerance could be maintained after induction. Secondly, we addressed whether PD-1/PD-L1 played a role in maintaining this tolerance. The results are reported herein.

\section{Materials and Method}

2.1. Mice. 8-10-week-old Balb/c ( $\mathrm{H}-2 \mathrm{~d})$ and $\mathrm{C} 3 \mathrm{H}(\mathrm{H}-2 \mathrm{k})$ were purchased from Charles River Animal facility (Beijing, China) and housed in the Animal Care facility at Xuanwu Hospital, Capital Medical University, Beijing. All mice were used following the Chinese governmental and Capital Medical University guidelines for animal welfare. This study was approved by the Capital Medical University Animal Ethics Committee. All mice used in this study were euthanized in a $\mathrm{CO}_{2}$ chamber with a $\mathrm{CO}_{2}$ meter connected to it to control $\mathrm{CO}_{2}$ flow as $1.5 \mathrm{~L} / \mathrm{min}$.

2.2. Dendritic Cell Culture and Preparation. Balb/c bone marrow derived immature dendritic cells (BM-iDCs) were cultured and irradiated by ultraviolet B (UVB) $\left(1200 \mathrm{~mJ} / \mathrm{cm}^{2}\right)$ following the protocol we reported previously $[5,6]$. After being irradiated, iDCs would initiate the process of apoptosis because of the DNA crosslinking induced by UVB irradiation. In our observation, $60-70 \%$ of UVB-irradiated iDCs underwent apoptosis $8 \mathrm{~h}$ after irradiation and almost all cells died $24 \mathrm{~h}$ after irradiation. Therefore, to avoid infusion of apoptotic cells at different stages of apoptosis, the irradiated iDCs were either injected immediately after irradiation or put on ice to stop biological activities of the cells and injected within $2 \mathrm{~h}$.

\subsection{Alloantigen Tolerance Induction and Adoptive CD4+ T} Cells Transfer. As previously reported $[5,6], \mathrm{C} 3 \mathrm{H}$ male mice received intravenous injection of UVB-irradiated Balb/c iDCs $\left(2 \times 10^{5}\right.$ cells/mouse $)$ or PBS once a week for 4 weeks and then plasma anti-donor antibodies were measured by flow cytometry (FCM, Canto, BD) following the protocol described previously [6] to confirm that the tolerance was successfully induced. Six weeks later, we challenged the mice with intravenous injection of $2 \times 10^{5} /$ mouse Balb/c spleen cells once a week for two weeks. Thereafter, we measured the anti-donor antibody levels using the method we reported previously $[5,6]$ with mild modifications. In brief, the antidonor antibody assay was a flow cytometric analysis of plasma levels of antibodies against donor cells. Donor spleen cells $\left(1 \times 10^{6}\right)$ in $60 \mu \mathrm{L}$ of PBS were incubated with $40 \mu \mathrm{L}$ of plasma collected from mice in different experimental groups as indicated and anti-CD4-PercP antibodies at room temperature for $30 \mathrm{~min}$. Then, the cells were washed twice with PBS and resuspended in $100 \mu \mathrm{L}$ PBS and incubated with secondary antibody, anti-mouse IgG-FITC at room temperature for $30 \mathrm{~min}$. The data were analyzed by flow cytometry. Samples with anti-mouse IgG-FITC staining positive were considered positive for anti-donor antibodies. Using CD4 T cell staining to represent spleen cells was for the purpose of eliminating the false positivity caused by Fc binding of mouse plasma IgG in antigen-presenting cells, mainly B cells.

For CD4+ T cell transfer studies, CD4+ T cells from C3H mice from two different groups used for the above experiments were prepared by negative selection with CD4+ T cell isolation kit (EasySep kit) according to the protocol from the manufacturer (StemCell Biotech). The purity of CD4+ T cells was around $95 \% .5 \times 10^{6}$ purified CD $4+$ T cells were adoptively transferred to naïve $\mathrm{C} 3 \mathrm{H}$ mice via tail vein injection. After the injection, all recipient $\mathrm{C} 3 \mathrm{H}$ mice were challenged with two weekly transfusions of $2 \times 10^{5} \mathrm{Balb} / \mathrm{c}$ spleen cells. One week after the second challenge, plasma samples were prepared and assayed for antibodies against Balb/c WBCs. In the above experiments, the mice were monitored twice a week until the endpoint of the experiments and then euthanized as described in Section 2.1.

2.4. In Vivo Alloantigen-Specific Immune Response Assay and Anti-PD-L1 Antibody Treatment. Tolerant C3H mice received Balb/c spleen cells $\left(1.5 \times 10^{7} /\right.$ mouse $)$ prelabeled with carboxyfluorescein diacetate succinimidyl ester (CFSE, from Invitrogen). In the meantime, $100 \mu \mathrm{g}$ of purified anti-mouse PD-L1 mAb (Biolegend, Clone 10F.9G2) or control IgG (Rat IgG, Sigma) was injected intraperitoneally (i.p.) into these mice, respectively. Nontolerant naïve $\mathrm{C} 3 \mathrm{H}$ mice receiving injection of CFSE-labeled Balb/c spleen cells served as an additional control group. Twenty-four hours later, peripheral blood mononuclear cells (PBMNCs) of all recipient mice were prepared and stained by anti-CD4-PercP antibody (BD BioScience, clone RM4-5). CFSE+CD4+ T cells were measured by flow cytometry. The percentage of CFSE+CD4+ T cells in total CD $4+\mathrm{T}$ cells served as a readout to demonstrate the acceptance of donor cells.

For examining the maintenance of humoral immune tolerance, the tolerant recipient $\mathrm{C} 3 \mathrm{H}$ mice 6 weeks after tolerance induction received intravenous injection of $\mathrm{Balb} / \mathrm{c}$ spleen cells $\left(2 \times 10^{5} /\right.$ mouse $)$ along with injection of antimouse PD-L1 mAb $(100 \mu \mathrm{g})$ or control IgG $(100 \mu \mathrm{g})$, once a week for two weeks. Thereafter, plasma samples were prepared and assayed for antibodies against Balb/c WBCs as described above.

In assessing how $\mathrm{PD}-1 / \mathrm{PD}-\mathrm{L} 1$ interaction in tolerant $\mathrm{C} 3 \mathrm{H}$ mice affected alloantigen-responding T cells from naïve $\mathrm{C} 3 \mathrm{H}$ mice, Balb/c spleen cells $\left(1 \times 10^{7} /\right.$ mouse) (as alloantigens) and CFSE-labeled naïve $\mathrm{C} 3 \mathrm{H}$ spleen cells $\left(1 \times 10^{7} /\right.$ mouse $)$ were injected intravenously (i.v.) into tolerant mice with anti-mouse PD-L1 mAb (100 $\mu \mathrm{g} /$ mouse) or control IgG (100 $\mu \mathrm{g} /$ mouse) at day 1 and day 3 . Naïve $\mathrm{C} 3 \mathrm{H}$ mice receiving injection of both types of cells served as an additional control. On day 4, the recipient mice were sacrificed and inguinal lymph node cells were prepared and stained with anti-CD4 and anti-CD8 fluorescent antibodies, and CFSElabeled CD4+ and CD8+ T cell proliferation was examined by flow cytometry and analyzed using FCS express software (De Novo software, Vancouver, Canada).

2.5. Mouse Skin Transplantation. Recipient C3H mice were prepared with four weekly infusions of UVB-iDCs from $\mathrm{Balb} / \mathrm{c}$ mice or PBS as described above. To assess the 
maintenance of tolerance, we performed skin transplantation 6 weeks after finishing tolerance induction. Syngeneic skin transplantation in Balb/c mice was also performed to ensure the success of our surgical procedure. The surgical procedure is as follows: donor skin grafts were from the ears of $\mathrm{Balb} / \mathrm{c}$ mice. The donor ears were surgically removed and placed in PBS on ice and then split and the dorsal flap was retained for transplant. $\mathrm{C} 3 \mathrm{H}$ allogeneic and $\mathrm{Balb} / \mathrm{c}$ syngeneic recipient mice were anesthetized and placed in lateral position. The transplant area was wetted with $75 \%$ alcohol; then the hairs were shaved and the operation area was cleaned with alcohol swab. In the area of skin preparation, $1 \mathrm{~cm}$ diameter circular flap was surgically removed and placed on the preprepared graft bed. Donor skin graft was carefully trimmed to fit the graft bed. The recipient mice were wrapped by a sterile bandage around the body to completely cover the surgical area and placed in a clean cage. All recipient animals were monitored on a daily basis. At day 6 after transplant, the bandage was removed and the graft was examined for the success of surgery and graft survival. The recipients were continued to be monitored daily for signs of rejection. When a graft showed signs of scabbing or contraction, skin graft rejection was considered. All mice in these experiments were euthanized using $\mathrm{CO}_{2}$ as described in Section 2.1 at the endpoint of the experiment.

\section{Result}

3.1. Infusion of UVB-iDCs to Allogeneic Recipients Induces Long-Lasting Alloantigen-Specific Tolerance, Which Is Transferable through Adoptive Transfer of CD4+ T Cells. Our previous study showed that four weekly transfusions of UVB-iDCs to allogeneic recipient mice induced tolerance to alloantigens [6]. In our allogeneic hematopoietic stem cell transplantation model, it appeared that this tolerance was maintained in the recipient mice 3 months after transplantation [5]. In these experiments, we sought to determine whether this tolerance could be maintained for a period of time after tolerance induction. We followed the same protocol reported previously [6], but, instead of performing assessment 1 week after the last treatment, we evaluated tolerance 6 weeks after finishing tolerance induction through alloantigen challenge by intravenous injection of allogeneic $\mathrm{Balb} / \mathrm{c}$ spleen cells. We found that $\mathrm{C} 3 \mathrm{H}$ mice tolerized by $\mathrm{Balb} / \mathrm{c}$ UVB-iDC treatment remained tolerant to alloantigen challenge (Figures 1(a), 1(b), and 1(c)), whereas nontolerant $\mathrm{C} 3 \mathrm{H}$ mice pretreated by injection of PBS developed highlevel anti-Balb/c antibodies in response to Balb/c alloantigen challenge (Figures 1(a), 1(b), and 1(c)). Similar to the results reported previously that CD4+ T cells from the tolerant mice could transfer tolerance [5], we found that this long-lasting immune tolerance could also be transferred to syngeneic naïve $\mathrm{C} 3 \mathrm{H}$ mice through adoptive transfer of $\mathrm{CD} 4+\mathrm{T}$ cells from the tolerant mice, demonstrating that CD4+ $\mathrm{T}$ cells from tolerant mice markedly suppressed alloantigen-induced anti-donor antibody development compared to CD4+ T cells transferred from immunized mice (Figures 2(a), 2(b), and $2(c))$. The above findings suggest that UVB-iDCs infusioninduced alloantigen immune tolerance can be maintained for long term, and CD4+ T cells play an important role for the maintenance of alloantigen tolerance.

3.2. Skin Graft Survival in Tolerant Mice Is Significantly Prolonged. To further address the strength and maintenance of alloantigen-specific tolerance induced by UVBiDC treatment, we performed allogeneic skin transplantation in tolerant and PBS-treated $\mathrm{C} 3 \mathrm{H}$ mice 6 weeks after tolerance induction. The results shown in Figures 3(a) and 3(b) demonstrated that skin graft survival was significantly prolonged in tolerant mice compared to nontolerant mice. The skin grafts were eventually rejected from the tolerant recipients (Figure 3(b)), suggesting that the tolerance was not sufficient in sustaining allogeneic skin graft survival in this most difficult organ transplantation model. As expected, syngeneic skin grafts were all survived (Figure 3), indicating no technical difficulty concurring in our skin transplantation experiment.

\subsection{PD-1/PD-L1 Blockade Breaks the Allogeneic Immune} Tolerance Induced by Infusion of UVB-iDCs. To determine whether PD-1/PD-L1 pathway plays a role in UVB-iDCinduced allogeneic tolerance, we employed anti-mouse PDL1 antibodies to block the PD-1 signaling in the mice with long-lasting tolerance during alloantigen challenge. We intravenously injected fluorescent dye, CFSE-labeled Balb/c spleen cells into $\mathrm{C} 3 \mathrm{H}$ mice tolerant to $\mathrm{Balb} / \mathrm{c}$ alloantigens, with treatment of anti-PD-L1 antibody, or control IgG. Nontolerant naïve $\mathrm{C} 3 \mathrm{H}$ mice receiving injection of CFSE-labeled $\mathrm{Balb} / \mathrm{c}$ spleen cells served as an additional control. In nontolerant control mice, all CFSE-labeled cells were rejected within $24 \mathrm{~h}$ after injection (Figures 4(a) and 4(b)). Fair numbers of CFSE-labeled cells remained in the tolerant recipient mice receiving control IgG treatment, whereas these numbers were significantly reduced upon PD-1/PD-L1 blockade by the treatment of anti-PD-L1 antibodies with a complete rejection in one of three mice (Figures 4(a) and 4(b)). Further, we assessed how PD-1/PD-L1 blockade affected anti-alloantigen antibody development upon alloantigen challenge. We showed that tolerant mice receiving control IgG treatment failed to develop any levels of anti-alloantigen antibodies upon alloantigen challenge (Figures 5(a) and 5(b)). However, tolerant mice receiving anti-PD-L1 treatment developed relatively high levels of anti-alloantigen antibodies, which nonetheless were still lower than nontolerant mice challenged with alloantigens based on mean fluorescent intensity (MFI) (Figure 5(c)). This result is consistent with the result shown above that there were still certain numbers of CFSE-labeled cells remaining in some of tolerant mice receiving anti-PD-L1 treatment (Figures 4(a) and 4(b)). These findings suggest that PD$1 / \mathrm{PD}$-L1 plays an important role in maintaining alloantigen tolerance in the tolerant mice.

3.4. PD-1/PD-L1 Interaction Is Required to Prevent Nä̈ve Alloantigen-Responding $T$ Cells from Being Activated in the Tolerant Mice. The results shown above suggest that tolerant $\mathrm{T}$ or $\mathrm{B}$ cells can be reinvigorated by alloantigen stimulation under PD-1/PD-L1 blockade. It is of interest to learn whether PD-1/PD-L1 interaction is essential in tolerant mice for 

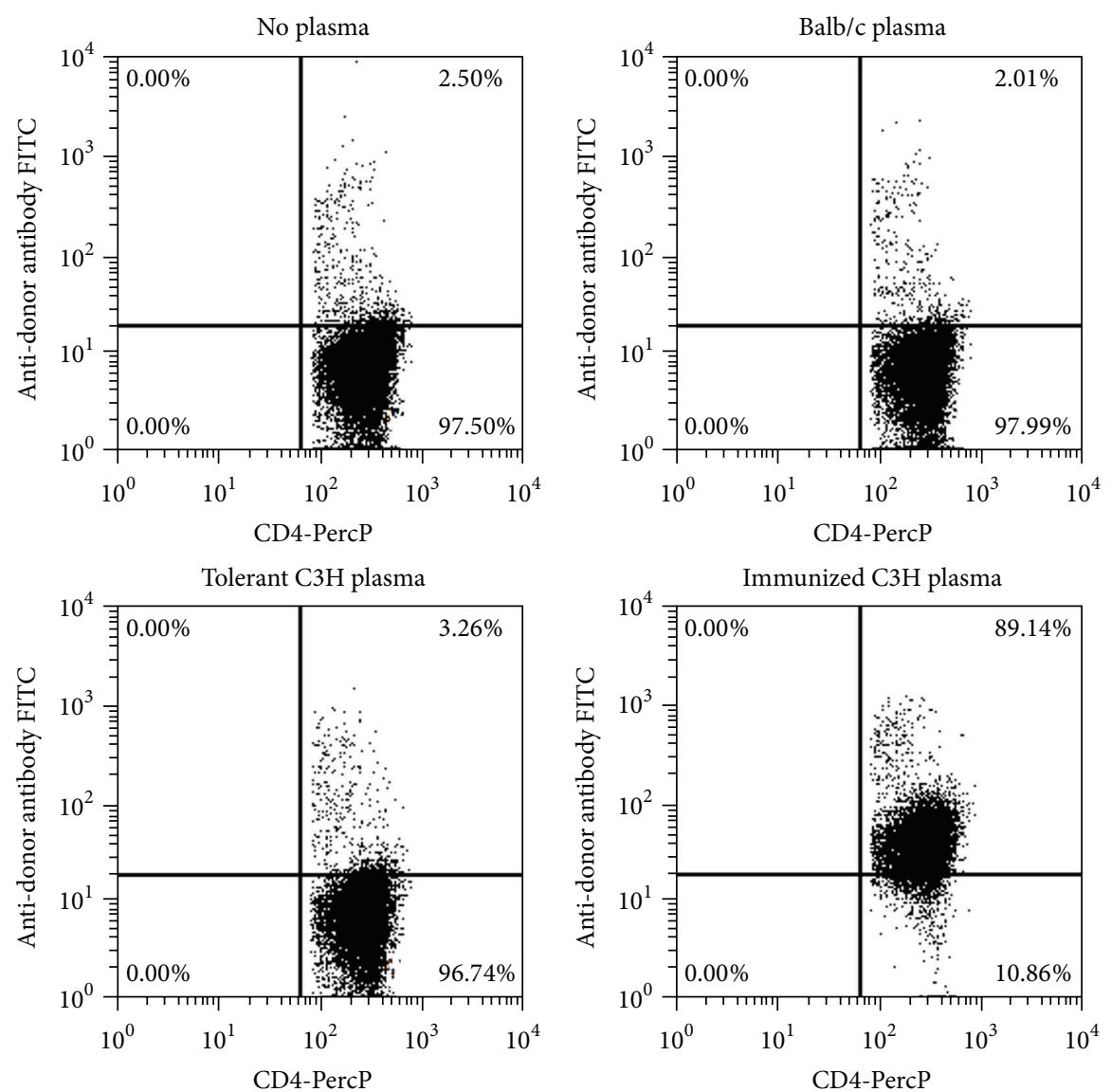

(a)

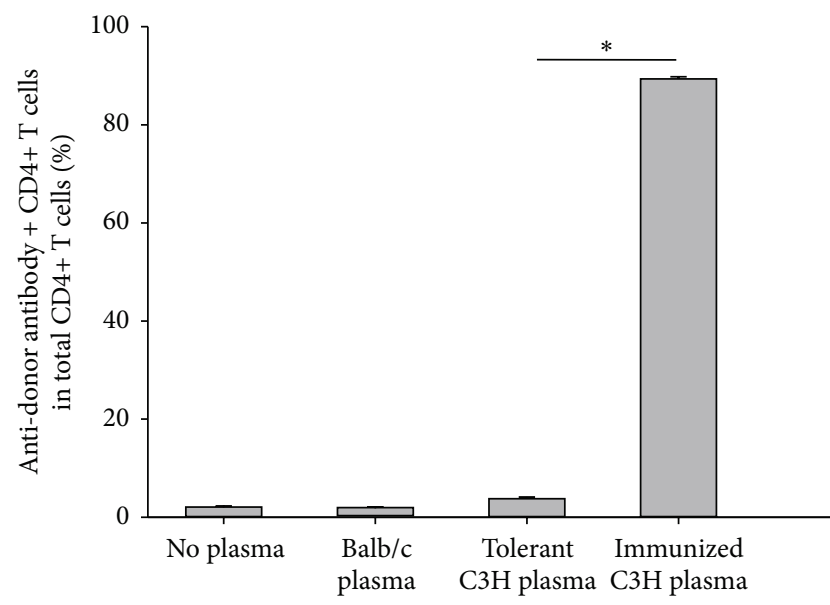

(b)

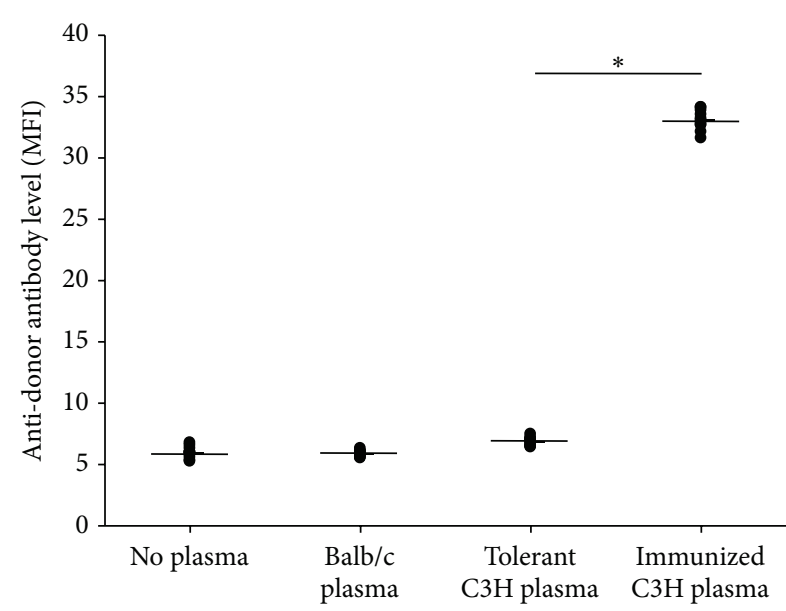

(c)

FIGURE 1: Alloantigen-specific tolerance induced by infusion of UVB-iDCs can be maintained for long term. (a) Recipient C3H mice (H2k) were treated with 4 weekly intravenous injections of donor Balb/c (H2d) UVB-iDCs or PBS (10 mice/group). Six weeks later, all mice were challenged by infusion of Balb/c spleen cells $\left(2 \times 10^{5} /\right.$ mouse $)$ once a week for two weeks. One week after the second challenge, plasma levels of anti-donor antibodies were examined. Naïve Balb/c mouse plasma samples were utilized for testing the background binding. Balb/c spleen cells with plasma added were blank controls. ((b) and (c)) The summary of anti-donor antibodies levels in both percentage and mean fluorescent intensity (MFI) is depicted, respectively. Data represent mean \pm standard error. ${ }^{*} P<0.05$. The $P$ values were calculated using Student's $t$-test. 

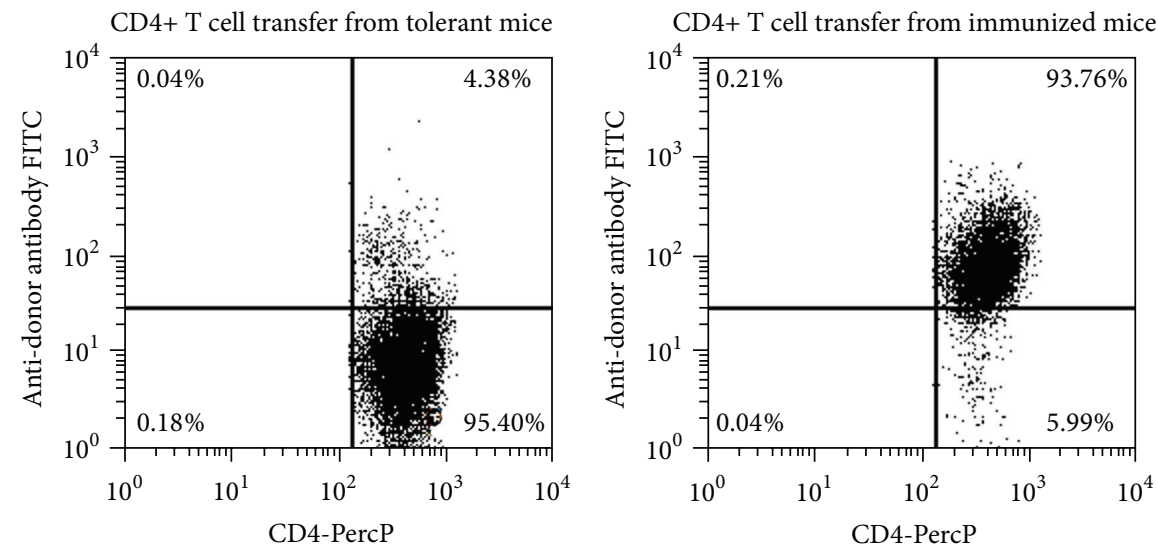

(a)

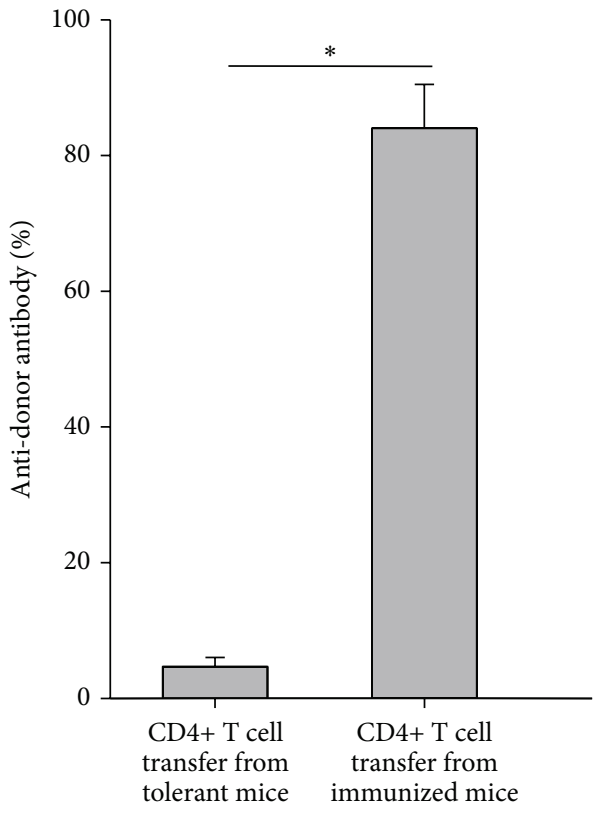

(b)

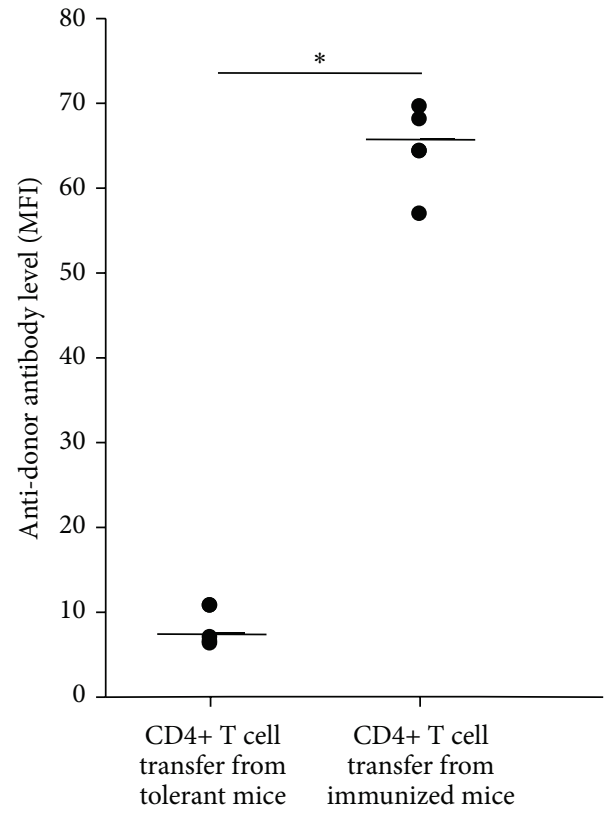

(c)

FIGURE 2: Alloantigen immune tolerance is transferable by adoptive transfer of CD4+ T cells from long-lasting tolerant mice. Splenic CD4+ T cells from $\mathrm{C} 3 \mathrm{H}$ mice used for the experiments in Figure 1 were prepared by negative selection using Easysep kits from StemCell Biotechnology Company. Given that all mice had been challenged by injection of Balb/c spleen cells, the PBS-treated C3H mice were all immunized as shown in Figure 1, and the two groups were designated as tolerant group and immunized group, respectively. CD4+ T cells were adoptively transferred into naïve $\mathrm{C} 3 \mathrm{H}$ mice $\left(5 \times 10^{6} \mathrm{CD} 4+\mathrm{T}\right.$ cells/mouse) $(5$ mice/group). One day after $\mathrm{CD} 4+\mathrm{T}$ cell transfer, all mice were challenged with two weekly transfusions of $2 \times 10^{5} \mathrm{Balb} / \mathrm{c}$ spleen cells. One week after the second antigen challenge, the development of antibodies against donor Balb/c WBCs was examined as described in Section 2. (a) A representative of each group was shown. ((b) and (c)) The summary of anti-donor antibody levels in percentage and MFI of each group was depicted, respectively. Data represent mean \pm standard error. ${ }^{*} P<0.05$. The $P$ values were calculated using Student's $t$-test.

controlling alloantigen-responding $\mathrm{T}$ cells that potentially arise later and never experience alloantigens. Those $\mathrm{T}$ cells could lead to allograft rejection or graft-versus-host disease if left unchecked in allogeneic transplantation. To assess whether PD-1/PD-L1 in those alloantigen tolerant mice keeps the alloantigen-responding $\mathrm{T}$ cells in check, we adoptively transferred CFSE-labeled naïve C3H spleen cells (syngeneic) along with Balb/c spleen cells (alloantigen) to the tolerant $\mathrm{C} 3 \mathrm{H}$ mice or naive $\mathrm{C} 3 \mathrm{H}$ mice. Thereafter, anti-PD-L1 or control IgG was administered to two groups of tolerant mice at day 1 and day 3, respectively. Four days later, we sacrificed the mice and prepared cells from inguinal lymph nodes and assessed the proliferation of injected CFSE-labeled $\mathrm{C} 3 \mathrm{H}$ syngeneic $\mathrm{CD} 4+$ and $\mathrm{CD} 8+\mathrm{T}$ cells not preexperiencing alloantigen, in response to injected $\mathrm{Balb} / \mathrm{c}$ spleen cells (alloantigen) in vivo. In comparison to control IgG-treated mice, CD4+ and CD8+ T cell proliferation in response to in vivo alloantigen stimulation was significantly enhanced in anti-PD-L1 treated mice, which was similar to the $\mathrm{T}$ cell proliferation levels in naïve recipient mice (Figure 6). 

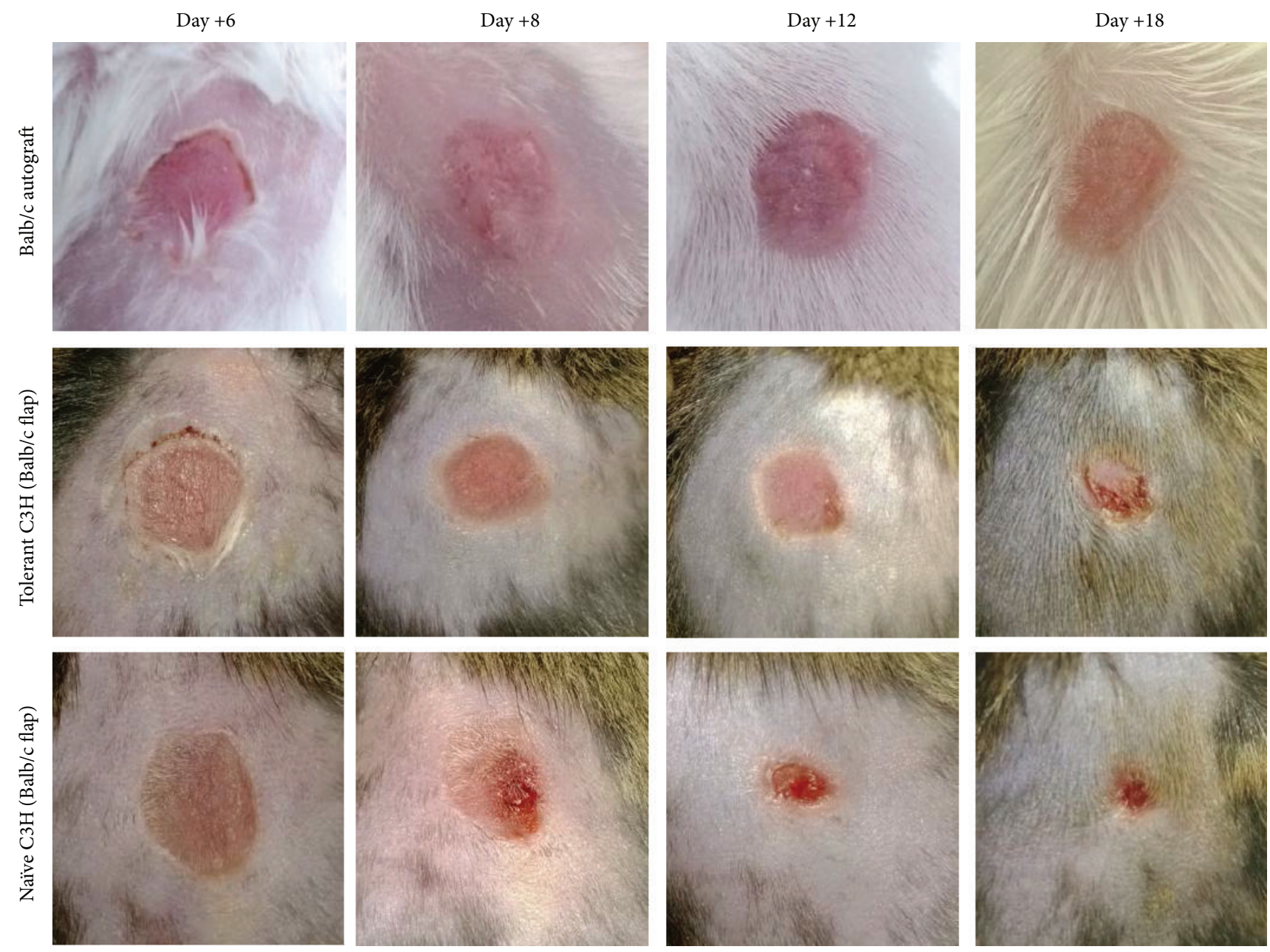

(a)

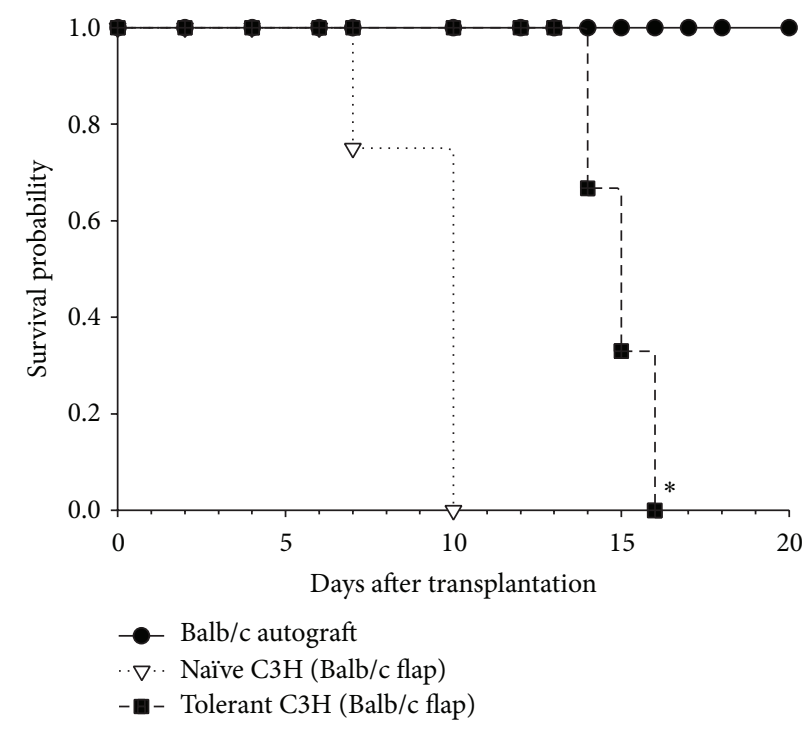

(b)

FIGURE 3: Tolerance induced by injection of UVB-iDCs prolongs the skin allograft survival. Six weeks after the last treatment for tolerance induction as described elsewhere, the tolerant and naïve $\mathrm{C} 3 \mathrm{H}$ mice were transplanted with $\mathrm{Balb} / \mathrm{c}$ skin grafts as described in Section 2 . The graft survival was monitored daily for 30 days. (a) The condition of a representative transplanted flap from each group is exhibited. (b) The graft survival of each group was shown. Six mice were included in each group. The survival data were analyzed by Log Rank test. ${ }^{*} P<0.05$ (tolerant group versus naïve group). 


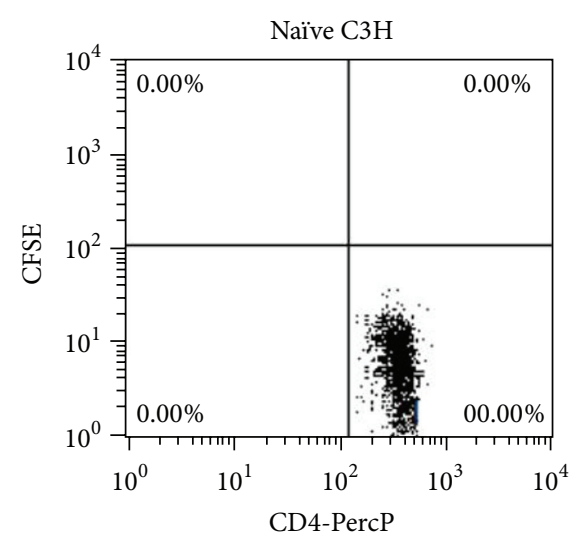

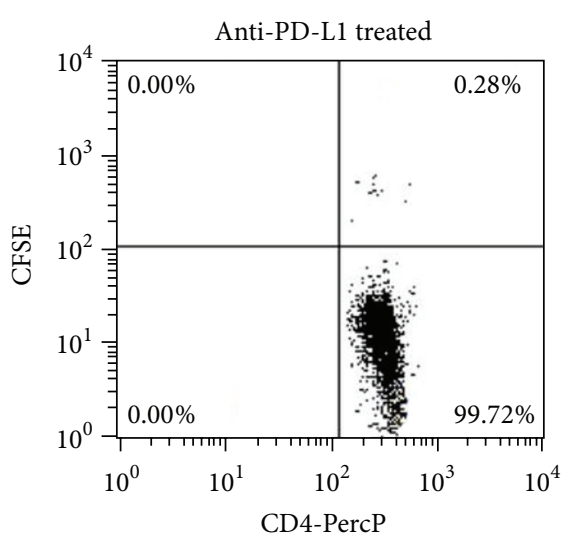

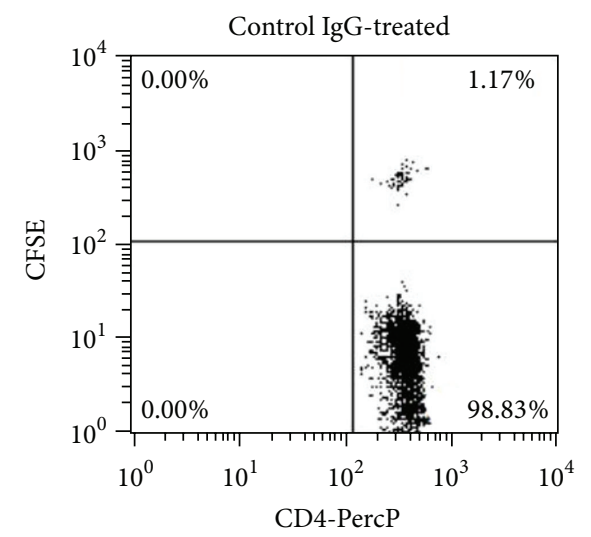

(a)

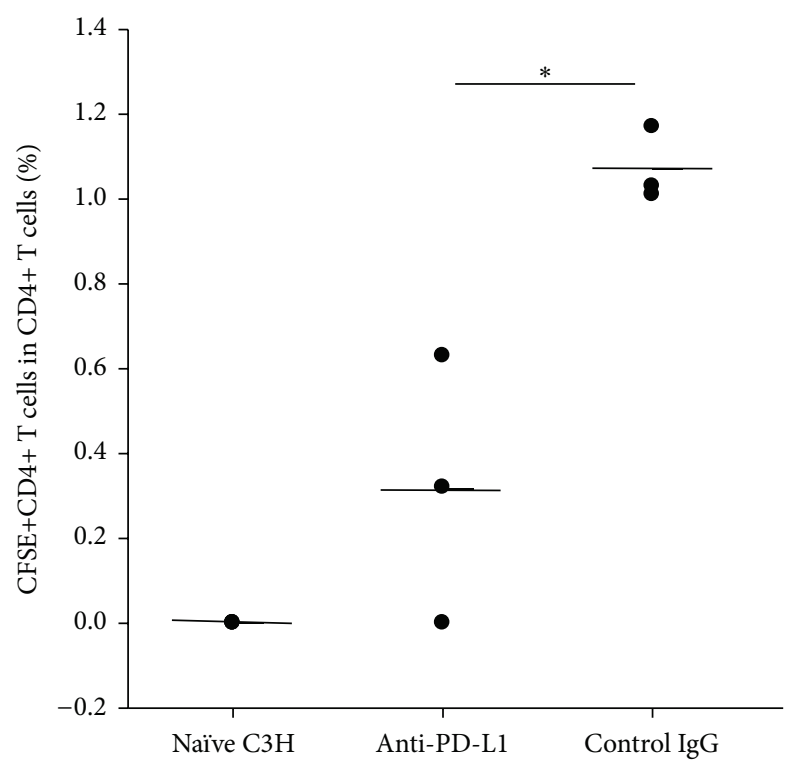

(b)

FIGURE 4: Anti-mouse PD-L1 antibody treatment enhances the rejection of intravenously injected Balb/c spleen cells in C3H mice with longlasting tolerance. The tolerant $\mathrm{C} 3 \mathrm{H}$ mice received purified anti-mouse PD-L1 mAb (100 $\mu \mathrm{g} / \mathrm{mouse})$ or control IgG (100 $\mu \mathrm{g} / \mathrm{mouse})$ along with administration of CFSE-labeled Balb/c spleen cells $\left(1.5 \times 10^{7} /\right.$ mouse $)$. Nontolerant C3H mice received the same numbers of CFSE-labeled $\mathrm{Balb} / \mathrm{c}$ spleen cells as control. Three mice were included in each group. 24 hours after injection, peripheral blood samples were collected from all mice and stained with anti-CD4-PercP antibody. The CFSE+CD4+ cells to total CD4+ T cells were examined by flow cytometry. (a) Flow cytometric data are exhibited from a representative mouse of each group. (b) The data summary of all mice in each group is depicted. Data represent mean \pm standard error. ${ }^{*} P<0.05$. The $P$ values were calculated using one-way ANOVA.

The above findings indicate that, in tolerant mice, PD-1/PDL1 interaction plays an important role in keeping potentially arising alloantigen-responding $\mathrm{T}$ cells in check and preventing them from being activated.

\section{Discussion}

We previously reported that transfusion of UVB-iDCs was able to induce immune tolerance across MHC barriers and this tolerance was associated with regulatory $\mathrm{CD} 4+\mathrm{T}$ cells $[5,6]$. However, it is unknown whether this tolerance state can be maintained for long term, which is highly desirable for allogeneic transplantation. In the present study, we assessed the tolerance maintenance 6 weeks after finishing tolerance induction. We found that tolerant mice failed to produce any levels of antibodies against alloantigens upon two weekly alloantigen challenges (Figure 1). These results are the same as those observed in the tolerant mice undergoing alloantigen challenge immediately after tolerance induction [6]. These findings suggest that UVB-iDC infusion-induced alloantigen tolerance could be maintained for at least 6 weeks after tolerance induction without any loss. Consistent with these results, we also observed that the tolerant mice failed to reject the intravenously injected CFSE-labeled traceable Balb/c allogeneic spleen cells, which were completely rejected in nontolerant naïve mice (Figure 4) through flow cytometric assessment of peripheral blood. In addition, we found those injected CFSE-labeled allogeneic spleen cells homed to host 

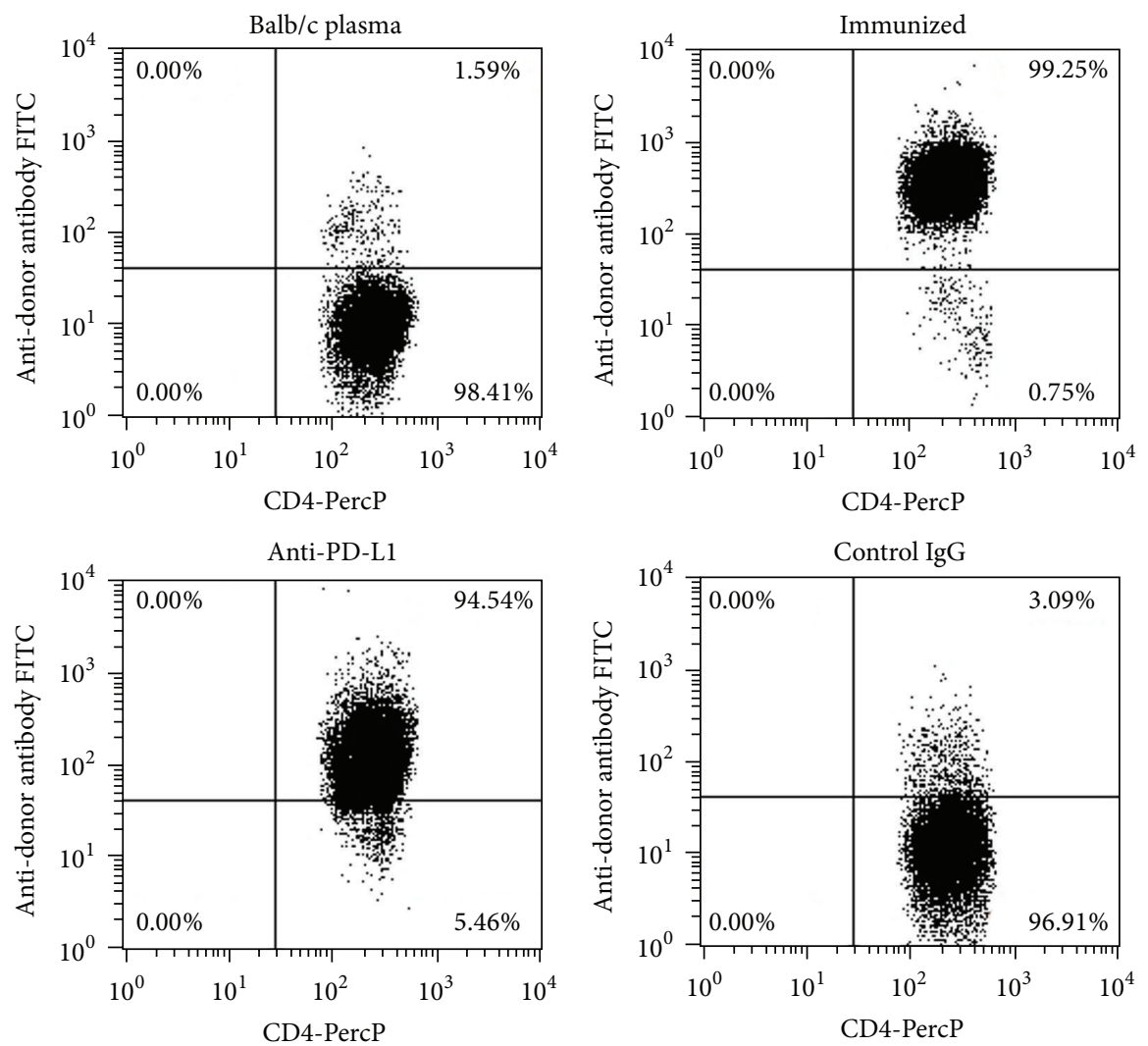

(a)

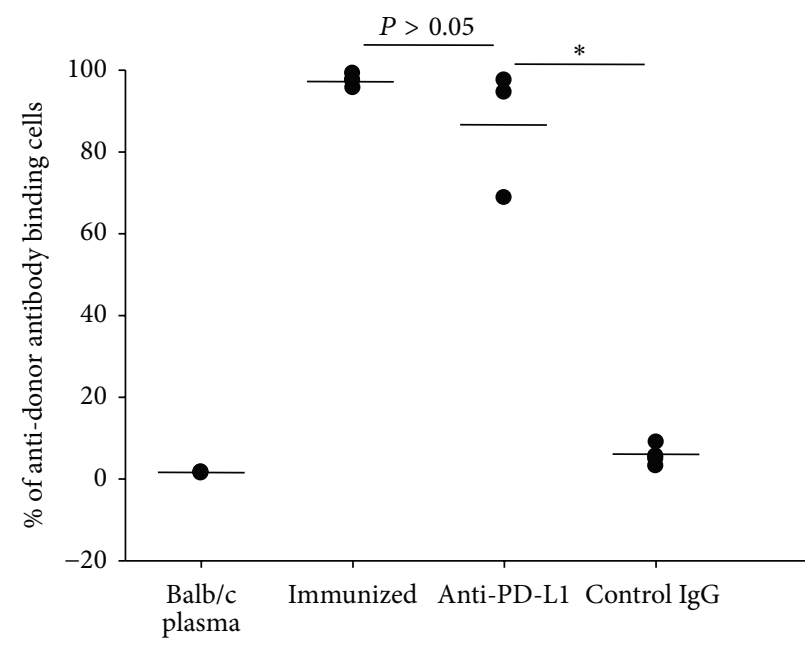

(b)

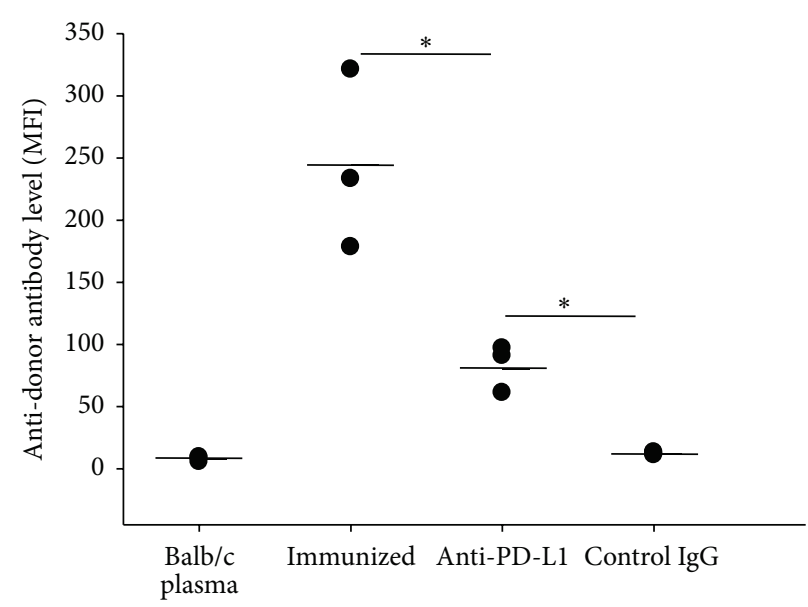

(c)

FIGURE 5: Anti-mouse PD-L1 antibody treatment partially recovers the development of antibodies against alloantigens in C3H mice with longlasting tolerance to $\mathrm{Balb} / \mathrm{c}$ alloantigens. Tolerant $\mathrm{C} 3 \mathrm{H}$ mice 6 weeks after tolerance induction were given alloantigen challenge by injection of $\mathrm{Balb} / \mathrm{c}$ spleen cells $\left(2 \times 10^{5} / \mathrm{mouse}\right)$ along with anti-mouse PD-L1 mAb (100 $\left.\mu \mathrm{g} / \mathrm{mouse}\right)$ or control IgG (100 $\left.\mu \mathrm{g} / \mathrm{mouse}\right)$ once a week for two weeks. The following week, plasma samples were prepared from all mice, and the levels of anti-donor (Balb/c) antibodies were examined as described elsewhere. The plasma samples from the Balb/c and naïve $\mathrm{C} 3 \mathrm{H}$ mice immunized by Balb/c spleen cells served as controls. We only gated CD4+ T cells to analyze anti-donor antibody levels to eliminate false positivity caused by B cell IgG Fc binding. (a) A representative mouse of each group was exhibited. (b) The summary of 3 mice in each group was depicted. Data represent mean \pm standard error. ${ }^{*} P<0.05$. $P$ values were calculated using one-way ANOVA. 

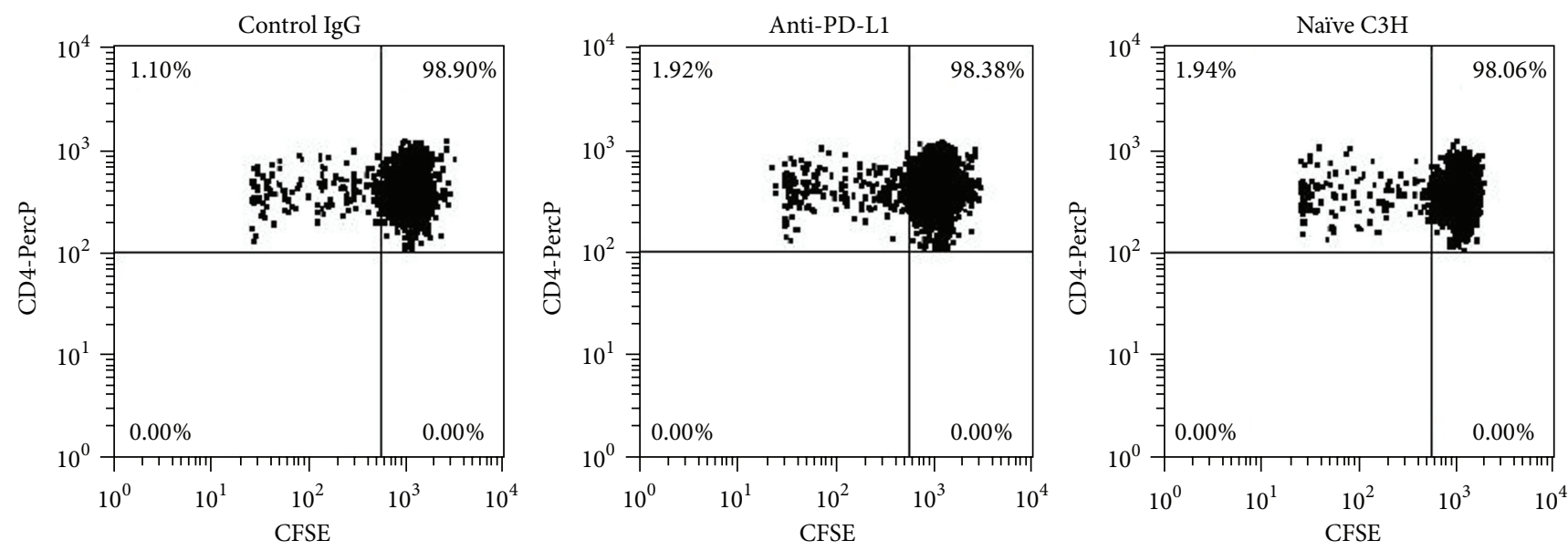

(a)
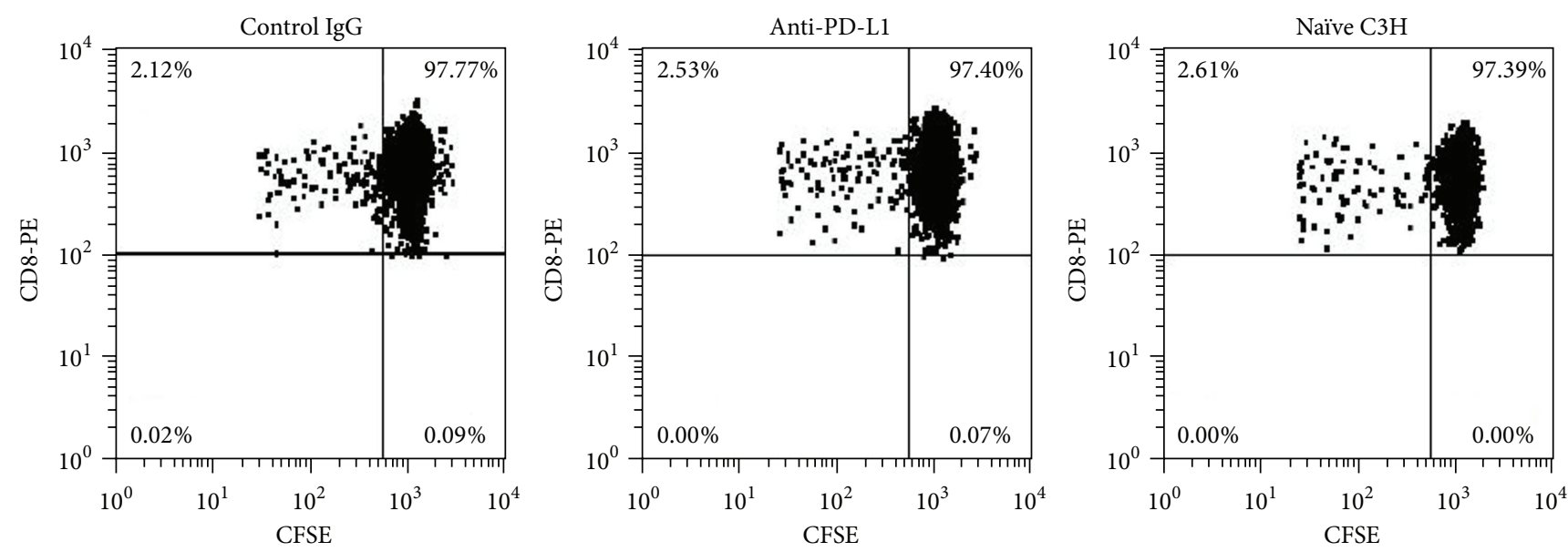

(b)

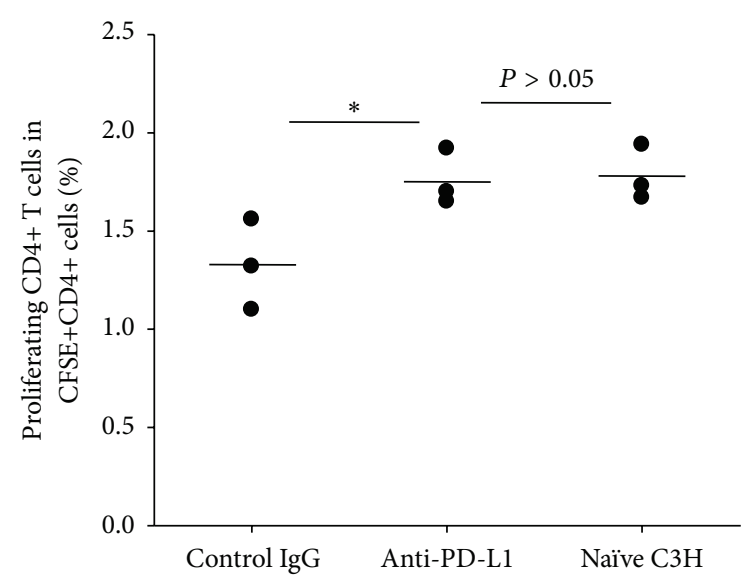

(c)

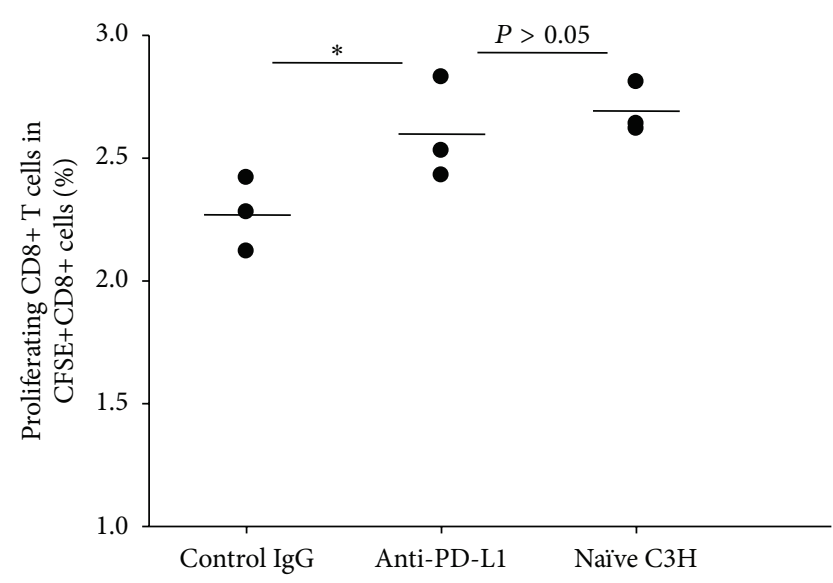

(d)

FIGURE 6: PD-1/PD-L1 interaction controls alloantigen-responding effector T cells in tolerant mice. C3H mice were treated with Balb/c UVBiDCs to induce alloantigen tolerance as described elsewhere. Six weeks later, CFSE-labeled naïve C3H spleen cells $\left(1 \times 10^{7} / \mathrm{mouse}\right)$ together with $\mathrm{Balb} / \mathrm{c}$ spleen cells $\left(1 \times 10^{7} /\right.$ mouse) were intravenously injected into the tolerant mice. One group received intraperitoneal injection of anti-mouse PD-L1 mAb (100 $\mu \mathrm{g} /$ mouse); the other group received control IgG (100 $\mu \mathrm{g} / \mathrm{mouse})$ at the same day when cells were injected. On day 3, the above treatments were administered again. One group of naïve $\mathrm{C} 3 \mathrm{H}$ mice was set up only receiving injection of both types of cells. On day 4 after cell injection, all mice were sacrificed and inguinal lymph nodes were collected and prepared for cell suspension. The proliferating CD4+ T cells and CD8+ T cells in CFSE + lymph node cells were analyzed by flow cytometry. (a) Representative flow cytometric data on CFSE-labeled CD4+ T cell proliferation in each group were shown; (b) representative flow cytometric data on CFSE-labeled CD8+ T cell proliferation in each group were shown; ((c) and (d)) the summary of CD4+ and CD8+ T cell proliferation was shown, respectively. Data represent mean \pm standard error. ${ }^{*} P<0.05$. The $P$ values were calculated using one-way ANOVA. 
lymph nodes and spleen in tolerant mice, which did not take place in nontolerant mice (data not shown). This tolerance assessment is a sensitive assay for evaluating allogeneic tolerance in vivo by looking at CFSE-labeled cells in the peripheral blood and could be a feasible method for future clinical evaluation of immune tolerance in allogeneic transplantation patients. Allogeneic skin transplantation is usually employed to test allogeneic tolerance. To assess whether tolerant mice 6 weeks after tolerance induction were able to accept allogeneic skin grafts, we performed allogeneic skin transplantation in tolerant and nontolerant mice. It is noted that, without any immunosuppression, the survival of allogeneic skin grafts was significantly prolonged in tolerant mice in contrast to that in nontolerant mice (Figure 3). These data further support that UVB-iDC-induced alloantigen tolerance is quite strong and durable.

We demonstrated previously that, among CD4+ T cells in tolerant mice, there were significantly increased IL-10producing and Foxp3+ regulatory T cells [5], which may play a crucial role in maintaining tolerance. In the current study, we assessed whether CD4+ T cells in the mice with longlasting tolerance remained functioning to maintain immune tolerance to alloantigens. We found that the tolerance was transferrable with adoptive CD4+ T cell transfer to syngeneic naïve recipient mice, showing that mice receiving CD4+ $\mathrm{T}$ cells from tolerant mice failed to produce antibodies against alloantigens upon alloantigen challenge (Figure 2). Interestingly, the results shown in Figures 1 and 2 are quite similar, indicating that CD4+ T cells exert critical effect on tolerance maintenance. Those CD4+ T cells with regulatory function are likely to be Foxp3+ Tregs and IL-10-producing Tr1 cells $[5,12]$.

PD-1/PD-L1 interaction has been considered playing an essential role in maintaining peripheral tolerance $[7,8,13,14]$. Blocking PD-1/PD-L1 interaction can drastically accelerate allograft rejection [15-17]. It was also reported that PD1/PD-L1 interaction is crucial for maintaining anti-CD3 treatment-induced immune tolerance to islet $\beta$ cell antigens in nonobese diabetic mouse model [18]. Administration of ethylene carbodiimide- (ECDI-) fixed allogeneic splenocytes failed to induce alloantigen tolerance in PD-L1 deficient mice, suggesting that PD-1/PD-L1 is required for alloantigen tolerance induced by ECDI-treated allogeneic splenocytes [11]. In the current study, we were interested in learning whether PD1/PD-L1 was required for maintaining alloantigen tolerance induced by UVB-iDC treatment. We employed our reliable and reproducible methods and tested the influence of PD1/PD-L1 blockade by anti-PD-L1 antibodies on immune tolerance to alloantigens upon alloantigen challenge. We showed that PD-1/PD-L1 blockade by anti-PD-L1 antibodies significantly promoted the rejection of infused CFSE-labeled allogeneic spleen cells (Figure 4) compared to control IgG antibody-treated tolerant mice. As expected, the nontolerant naive mice completely rejected the infused CFSE-labeled allogeneic spleen cells. In line with this finding, the levels of antibodies against alloantigens in response to alloantigen challenge in tolerant mice were largely recovered by the treatment of anti-PD-L1 antibodies but failed to reach the levels of nontolerant naïve mice challenged with alloantigens
(Figure 5). The above findings indicate that PD-1/PD-L1 interaction actively participates in maintaining allogeneic tolerance induced by UVB-iDC treatment. Incomplete recovery of immune response to alloantigen challenge might be attributed to incomplete blockade of $\mathrm{PD}-1 / \mathrm{PD}-\mathrm{L} 1$ interaction because we only utilized one dose $(100 \mu \mathrm{g} / \mathrm{mouse})$, which might not be the optimal dose to completely block PD-1/PDL1 interaction. Another possibility is that other tolerance maintenance mechanisms may also be involved. A dose study for anti-PD-L1 antibodies or PD-L1 deficient mouse model may be needed to address whether PD-1/PD-L1 is the only factor to be involved in maintaining the tolerance induced by UVB-iDC treatment.

Finally, we investigated how the tolerance state in tolerant mice affected alloantigen-responding $\mathrm{T}$ cells that never experienced alloantigens and whether PD-1/PD-L1 interaction was also involved in this process. We injected CFSE-labeled syngeneic spleen cells from naïve $\mathrm{C} 3 \mathrm{H}$ mice into tolerant $\mathrm{C} 3 \mathrm{H}$ recipients to serve as responder cells, with simultaneous injection of allogeneic Balb/c spleen cells as allogeneic stimulators. One group was treated with anti-PD-L1 antibodies and the other group received control IgG treatment. As shown in Figure 6, blockade of PD-1/PD-L1 interaction significantly increased the proliferation of injected CFSE-labeled CD4+ and CD8+ $\mathrm{T}$ cells, suggesting that $\mathrm{PD}-1 / \mathrm{PD}-\mathrm{L} 1$ plays an important role in keeping alloantigen-responding $\mathrm{T}$ cells in check. This effect may be through induced alloantigenspecific regulatory $\mathrm{T}$ cells as described in our previous study [5]. PD-1 has been reported to be expressed on regulatory $\mathrm{T}$ cells [19]. Our data show that CD4+ T cells from UVB-iDCtreated mice express higher levels of PD-1 (Supplemental Figure 1, in Supplementary Material available online at http:// dx.doi.org/10.1155/2016/2419621), and those CD4+ T cells might gain regulatory function. Thus, UVB-iDC treatmentinduced alloantigen-specific regulatory $\mathrm{T}$ cells may control the potential alloantigen-specific effector T cells through PD1/PD-L1 interaction [20, 21].

Collectively, the present study demonstrates that UVBiDC infusion-induced allogeneic immune tolerance is long lasting, and PD-1/PD-L1 interaction plays an important role in the maintenance of immune tolerance.

\section{Competing Interests}

The authors have declared that there are no competing interests.

\section{Acknowledgments}

This study was supported by National Natural Science Foundation of China (81172854 and 81240015 to Chang-Qing Xia).

\section{References}

[1] N. Angaswamy, V. Tiriveedhi, N. J. Sarma et al., "Interplay between immune responses to HLA and non-HLA self-antigens in allograft rejection," Human Immunology, vol. 74, no. 11, pp. 1478-1485, 2013. 
[2] E. H. Warren, X. C. Zhang, S. Li et al., "Effect of MHC and non-MHC donor/recipient genetic disparity on the outcome of allogeneic HCT," Blood, vol. 120, no. 14, pp. 2796-2806, 2012.

[3] I. K. H. Poon, C. D. Lucas, A. G. Rossi, and K. S. Ravichandran, "Apoptotic cell clearance: basic biology and therapeutic potential," Nature Reviews Immunology, vol. 14, no. 3, pp. 166180, 2014.

[4] M. R. Elliott and K. S. Ravichandran, "Clearance of apoptotic cells: implications in health and disease," The Journal of Cell Biology, vol. 189, no. 7, pp. 1059-1070, 2010.

[5] Y. Guo, L. Zhang, S. Wan et al., "Tolerance induction between two different strains of parental mice prevents graft-versushost disease in haploidentical hematopoietic stem cell transplantation to F1 mice," Biochemical and Biophysical Research Communications, vol. 446, no. 4, pp. 1035-1041, 2014.

[6] C.-Q. Xia and K.-J. Kao, "Induction of immune tolerance across major histocompatibility complex barrier by transfusion of ultraviolet B-irradiated immature dendritic cells," Transfusion, vol. 45, no. 2, pp. 181-188, 2005.

[7] L. M. Francisco, P. T. Sage, and A. H. Sharpe, "The PD-1 pathway in tolerance and autoimmunity," Immunological Reviews, vol. 236, no. 1, pp. 219-242, 2010.

[8] M. E. Keir, M. J. Butte, G. J. Freeman, and A. H. Sharpe, "PD1 and its ligands in tolerance and immunity," Annual Review of Immunology, vol. 26, pp. 677-704, 2008.

[9] T. Okazaki and T. Honjo, "The PD-1-PD-L pathway in immunological tolerance," Trends in Immunology, vol. 27, no. 4, pp. 195201, 2006

[10] Y. Z. Yuan, C. Blank, and T. F. Gajewski, "Negative regulation of T-cell function by PD-1," Critical Reviews in Immunology, vol. 24, no. 4, pp. 229-237, 2004.

[11] X. Luo, K. L. Pothoven, D. McCarthy et al., "ECDI-fixed allogeneic splenocytes induce donor-specific tolerance for longterm survival of islet transplants via two distinct mechanisms," Proceedings of the National Academy of Sciences of the United States of America, vol. 105, no. 38, pp. 14527-14532, 2008.

[12] K.-J. Kao, E. S. Huang, and S. Donahue, "Characterization of immunologic tolerance induced by transfusion of UV-Birradiated allogeneic mononuclear leukocytes," Blood, vol. 98, no. 4, pp. 1239-1245, 2001.

[13] S. Kasagi, S. Kawano, and S. Kumagai, "PD-1 and autoimmunity," Critical Reviews in Immunology, vol. 31, no. 4, pp. 265-295, 2011.

[14] M. E. Keir, L. M. Francisco, and A. H. Sharpe, "PD-1 and its ligands in T-cell immunity," Current Opinion in Immunology, vol. 19, no. 3, pp. 309-314, 2007.

[15] N. Koga, "Blockade of the interaction between PD-1 and PD-L1 accelerates graft arterial disease in cardiac allografts," Arteriosclerosis, Thrombosis, and Vascular Biology, vol. 24, no. 11, pp. 2057-2062, 2004.

[16] M. Morita, M. Fujino, G. Jiang et al., "PD-1/B7-H1 interaction contribute to the spontaneous acceptance of mouse liver allograft," American Journal of Transplantation, vol. 10, no. 1, pp. 40-46, 2010.

[17] K. Tanaka, M. J. Albin, X. Yuan et al., "PDL1 is required for peripheral transplantation tolerance and protection from chronic allograft rejection," The Journal of Immunology, vol. 179, no. 8, pp. 5204-5210, 2007.

[18] B. T. Fife, I. Guleria, M. G. Bupp et al., "Insulin-induced remission in new-onset NOD mice is maintained by the PD-1-PD-L1 pathway," The Journal of Experimental Medicine, vol. 203, no. 12, pp. 2737-2747, 2006.
[19] P. T. Sage, L. M. Francisco, C. V. Carman, and A. H. Sharpe, "The receptor PD-1 controls follicular regulatory T cells in the lymph nodes and blood," Nature Immunology, vol. 14, no. 2, pp. 152-161, 2013.

[20] Y. Kitazawa, M. Fujino, Q. Wang et al., "Involvement of the programmed death-1/programmed death-1 ligand pathway in CD4+CD25+ regulatory T-cell activity to suppress alloimmune responses," Transplantation, vol. 83, no. 6, pp. 774-782, 2007.

[21] X. Guo, Y. Jie, D. Ren et al., "In vitro-expanded $\mathrm{CD} 4{ }^{+} \mathrm{CD} 25^{\text {high }}$ Foxp $3^{+}$regulatory $\mathrm{T}$ cells controls corneal allograft rejection," Human Immunology, vol. 73, no. 11, pp. 1061-1067, 2012. 


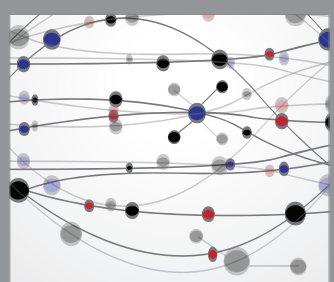

The Scientific World Journal
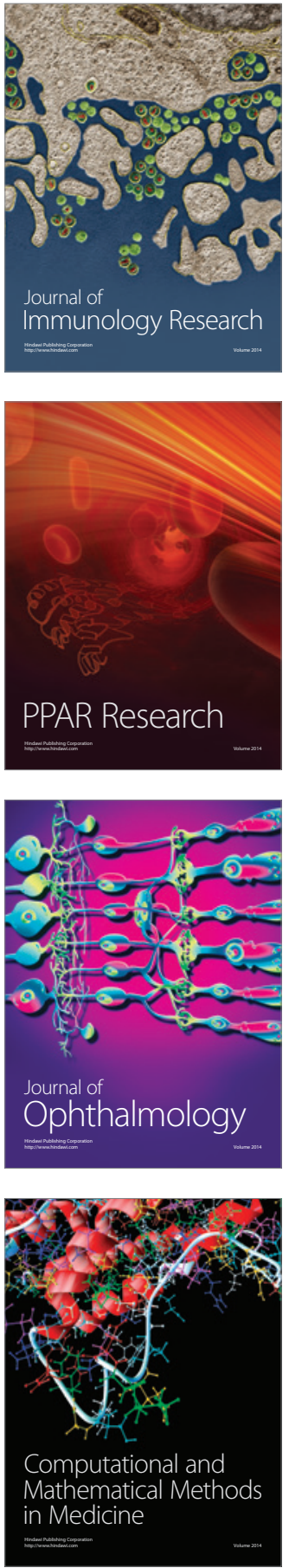

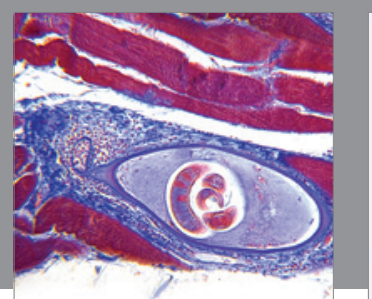

Gastroenterology Research and Practice

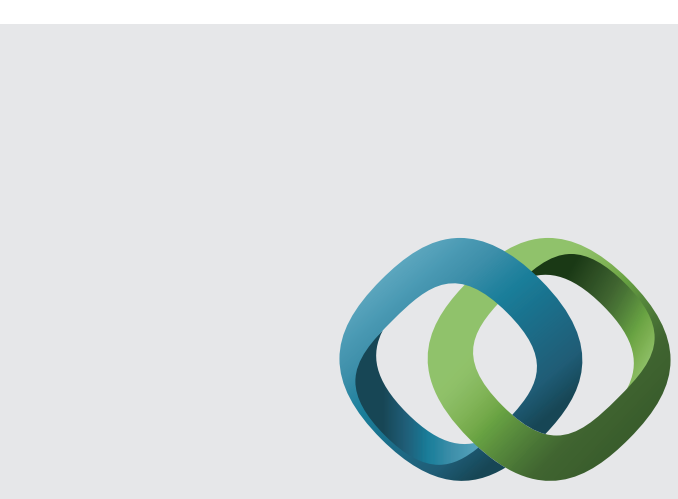

\section{Hindawi}

Submit your manuscripts at

http://www.hindawi.com
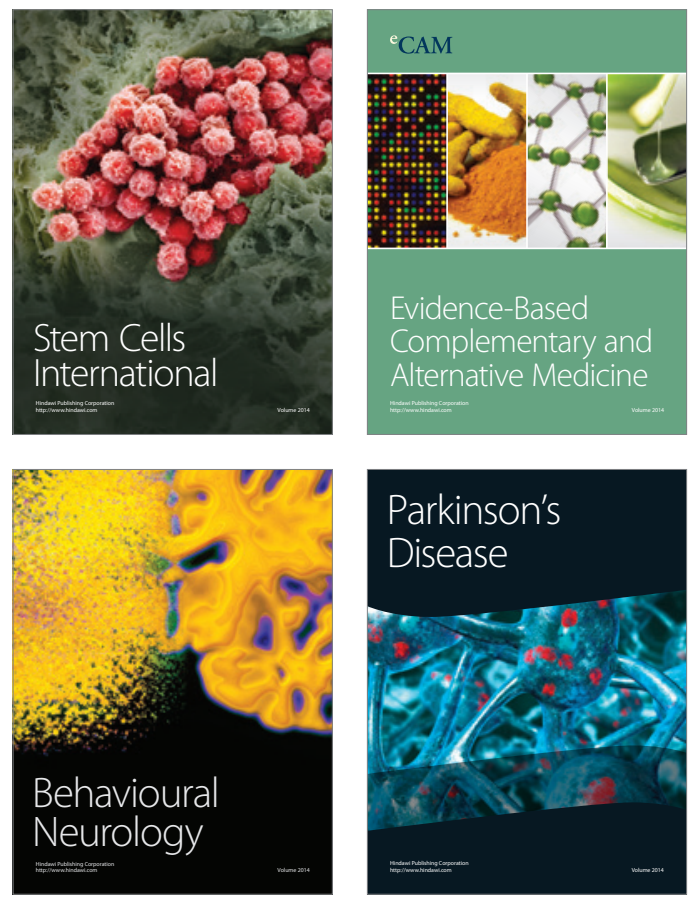
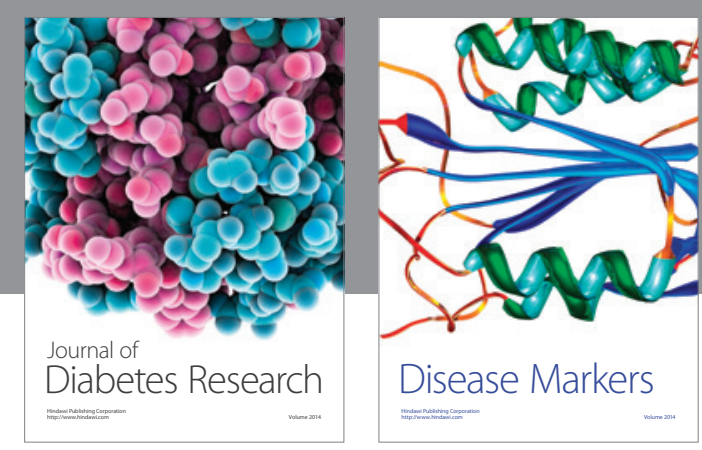

Disease Markers
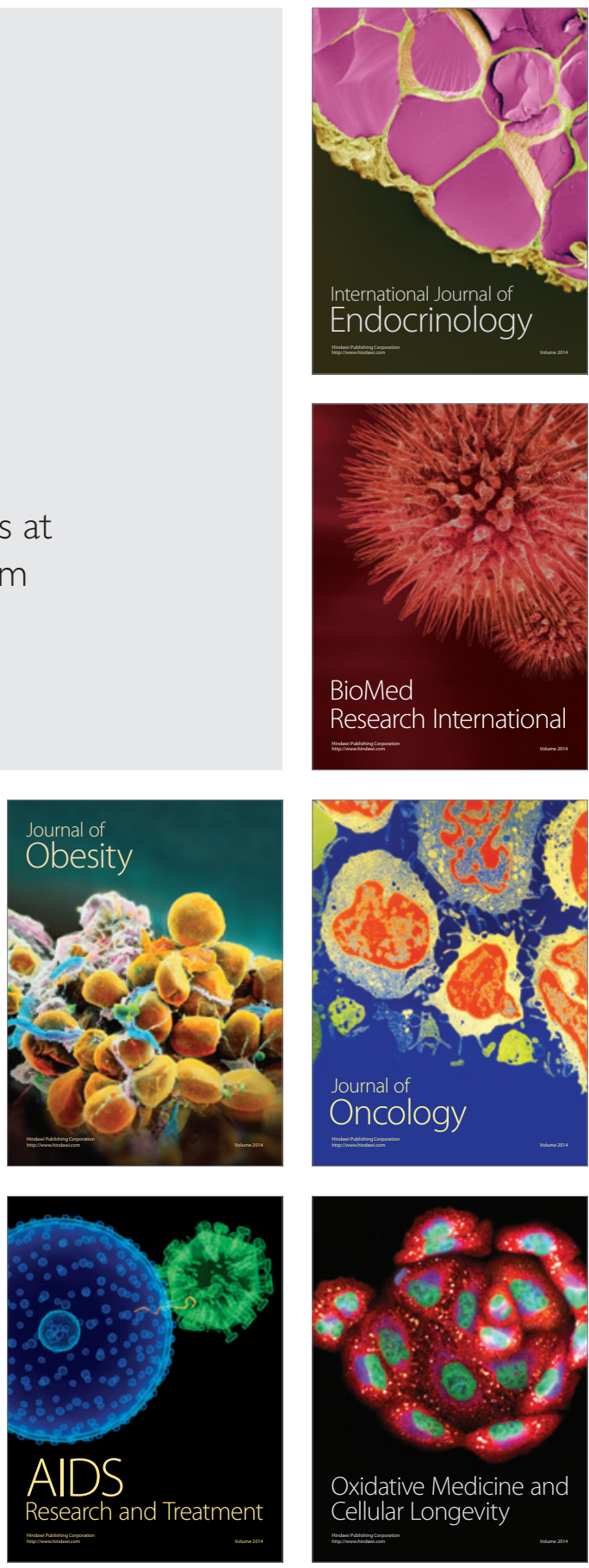